\title{
„MITOLOGIZACJA INTELEKTUALISTÓW” W ROZWAŻANIACH HAGIOGRAFICZNYCH
}

Pięćdziesiąt lat temu nasz wybitny socjolog Jan Szczepański podniósł problem mitologizacji intelektualistów ${ }^{1}$. W swoich rozważaniach zastanawiał się jedynie nad socjologicznymi i filozoficznymi analizami funkcji zawodów umysłowych. Zauważył, że większość tych analiz przekształcała się w mitologizowanie intelektualistów. Poszukując więc odpowiedzi na pytanie o mitologizację intelektualistów, musiał wpierw rozważyć kwestię ich statusu. Odpowiedź na pytanie, kim byli owi intelektualiści, nie była taka oczywista. Podstawowa kwestia wiązała się ze zmiennością ujęć definicyjnych w odniesieniu do kategorii pracowników umysłowych. Ta różnorodność miała znów wynikać nie tylko z różnych punktów widzenia poszczególnych nauk zajmujących się różnymi aspektami działalności intelektualnej, lecz także z różnych celów praktycznych i politycznych, na podstawie których określano doniosłość tych funkcji. Wpływ na definiowanie funkcji zawodowych intelektualistów miała jeszcze różnorodność wyznawanych teorii rozwoju społecznego (Szczepański 1962: 6).

Analiza tej wielości definicji poszła $w$ dwóch kierunkach, tj. formalnej i socjologicznej. W pierwszym przypadku chodziło o stwierdzenie, na podstawie jakich kryteriów zaliczano pewne kategorie ludzi do intelektualistów. W drugim zaś o rozpatrywanie definicji jako narzędzi, za pomocą których rozprawiano się z określonymi problemami społecznymi. Każda z definicji miała swoją genezę w określonej sytuacji społecznej formułowanej jako część pewnej teorii społecznej, usiłującej rozwiązać społecznie czy politycznie ważne problemy dla

\footnotetext{
${ }^{1}$ Najpierw w pracy Intellectuals in Contemporary Societies, Part I, Stanford, Center for Advanced Study in the Behavioral Sciences, później w polskim streszczeniu dwóch rozdziałów tej pracy: Mitologizacja intelektualistów, zamieszczonym w „Studiach Socjologicznych”.
} 
jej autora. Jak zauważył J. Szczepański, definicje te trzeba starać się zrozumieć jako narzędzia, za pomocą których autorzy rozwiązywali niepokojące ich problemy praktyczne i teoretyczne. Rozwiązując bowiem jakąś praktyczną sytuację społeczną, czyniono to zawsze z perspektywy określonej teorii rozwoju społecznego, i obojętne było, czy teorii precyzyjnie sformułowanej, czy jedynie nieświadomie założonej (Szczepański 1962: 7). Analizując zatem konkretną definicję, należy dociekać, jaki społeczny problem praktyczny bądź polityczny autor starał się za jej pomocą rozwiązać. Każdy bowiem okres historyczny wnosił inne problemy do rozwiązania.

Zależność przyjmowanej definicji od praktycznego zaangażowania i od przyjętej teorii postępu społecznego wyraźnie wystąpiła już w pierwszej nowożytnej definicji intelektualistów sformułowanej przez Francisa Bacona (1826: 37). Wprowadził on termin ,intellectualists" dla oznaczenia ludzi, którzy zagłębili się w kontemplacji swojego własnego umysłu i swojego świata. Zdaniem F. Bacona, ludzie podpadający pod przyjętą definicję nie przyczyniają się do postępu wiedzy empirycznej, a ich postawa jest przeszkodą w jej rozwoju. Definicja ta oznaczała nazwą intellectualists specjalną kategorię myślicieli i była podyktowana rozważaniami nad ich rolą $\mathrm{w}$ postępie nauk, a zatem i w postępie społecznym. Późniejsze definicje, formułowane zwłaszcza od drugiej połowy XIX w., wyróżniały różne typy intelektualistów, w zależności od przypisywanej im funkcji społecznej. Najbardziej charakterystyczną definicję sformułował Julien Benda, nazywając tych ludzi klerkami, których działalność nie jest z zasady skierowana na osiągnięcie celów i korzyści praktycznych (Benda 2003). Zadaniem klerków J. Bendy jest rozwijanie odwiecznych ludzkich wartości, wskazywanie dróg postępowania, pouczanie władców i mas, zaślepionych namiętnościami politycznymi i/lub ekonomicznymi, mówienie o tym, co stanowi istotną wartość życia ludzkiego.

Stawiając pytanie o podstawę działania klerków, o źródła ich wiedzy i siły moralnej do przeciwstawiania się i władcom, i masom, przyjmujemy za J. Bendą, że intelektualista w większym stopniu uczestniczy w wiecznym i boskim Logosie niż pozostała część społeczeństwa. Takie myślenie można odnieść do każdej epoki historycznej i każdego społeczeństwa. Czy zapotrzebowanie na takie działanie mogło wystąpić w państwie morawskim w IX w.? Wydaje się, że z podobną sytuacją mamy do czynienia w przypadku uczniów i hagiografów świętych Konstantyna/Cyryla i Metodego, którzy w latach 80. IX w. znaleźli się w opozycji do władzy książęcej i do zdecydowanie nieprzychylnej im części społeczeństwa. Otóż, zarysowany w Żywocie Metodego konflikt jego uczniów, oświeconych 
stróżów jego dzieła, z obskurantami społeczeństwa wielkomorawskiego, nie był wyłącznie konfliktem o wartości. Był to konflikt między dwoma obrządkami liturgicznymi, a tak naprawdę był to konflikt między przedstawicielami dwóch programów politycznych, konflikt zaostrzony walką o wpływy na dworze księcia Świętopełka Wielkiego ${ }^{2}$.

Podstawy koncepcyjne intelektualnego działania uczniów Konstantyna i Metodego zrodziły się w walce $\mathrm{z}$ wrogimi tendencjami części kleru, będącego zwolennikiem obrządku łacińskiego oraz z obawy przed skutkami zwycięstwa duchowieństwa skupionego wokół biskupa Wichinga, adwersarza arcybiskupa Metodego. W tych warunkach ,klerk” obrządku słowiańskiego to strażnik podstawowych wartości chrześcijańskich i sprawiedliwości dziejowej. Wyraźnie tu pasuje obraz idealnego klerka, nakreślony przez J. Bendę, gdyż nie jest to kategoria zawodowa czy warstwa społeczna, ale typ myśliciela i mędrca, wskazującego drogę cnót. Takie określenie zawiera implicite pewną teorię postępu społecznego. Według niej podstawowymi czynnikami postępu społecznego są niezachwiana wiara, rozum i sprawiedliwość. Ludzie pilnujący ich przestrzegania pchają ludzkość naprzód, bronią przed regresem, przed ruchami nierozumnymi i niesprawiedliwymi. Definicja J. Bendy i stojąca za nią teoria są przykładem definiowania intelektualistów jako kategorii określonej przez stosunek do wartości odwiecznych. Według J. Szczepańskiego (1962: 10), definicja J. Bendy zarysowuje pewien ideał, który określa stan pożądany i najlepszy, a do którego prowadzi wiara, rozum i sprawiedliwość.

Blisko tej definicji są inne, które charakteryzują intelektualistów przez ich stosunek do kultury. Przy czym pojęcie „kultura” jest rozumiane wieloznacznie i przy posługiwaniu się tym typem definicji intelektualistów definiuje się bardzo różnie. Seymur M. Lipset uważa za intelektualistów tych wszystkich, którzy tworzą i rozprzestrzeniają kulturę, ten symboliczny świat, do którego włącza się sztukę, naukę i religię. Tak zdefiniowana kultura jest zespołem czynników utrzymujących spójność grup, decydujących o ciągłości i o rozwoju społeczeństw. Słowo „kultura” może być używane w definicjach intelektualistów również w innym sensie. Za człowieka kultury może uchodzić człowiek o osobowości dobrze zharmonizowanej, łączący poglądy intelektualne, moralne i estetyczne we wspólny pogląd na świat. Można zatem widzieć zadania intelektualistów w tworzeniu poglądu na świat, dającego systematyczne wyjaśnienie podstawowych problemów ludzkiej egzystencji i wyjaśnienie sensu ludzkiego życia. Zadaniem intelektualistów według tej koncepcji, wyłożonej w książce José Ortegi y Gasseta

\footnotetext{
${ }^{2} \mathrm{Z}$ Żywotów Konstantyna i Metodego korzystam według wydania w polskim przekładzie w zestawieniu z dołączonym tekstem staro-cerkiewno-słowiańskim: Żywoty Konstantyna i Metodego (obszerne), (2000).
} 
(2008), jest spirytualizacja życia społecznego, uszlachetnianie dążeń mas, wskazywanie wyższych celów. Zanik elity kulturalnej i zmniejszenie jej wpływów powoduje odrodzenie prymitywizmu i barbarzyństwa. Kryzys kultury obrządku słowiańskiego na Morawach polegał na tym, że masy zdominowały elitę kulturalną, a na jej miejsce weszli ludzie o specjalizacji łacińskiej.

Szeroko rozpowszechniona została koncepcja intelektualistów jako ludzi idei, jako twórców określonego poglądu na świat i odpowiedniej wizji świata, a także jako tworzących kryteria określające stosunek człowieka do świata, do społeczeństwa i Boga (Aron 2000). Według tej koncepcji intelektualista jest oderwany od bieżącej praktyki życia zbiorowego przez naturę swoich zadań. Niejako z wysokości określa on sens życia ludzkiego, wyjaśnia jego przeznaczenie, uszlachetnia dążenia człowieka i zwalcza biologiczne popędy natury ludzkiej. W tym ujęciu kultura jest najwyższą wartością ludzką, a intelektualista, tworząc kulturę, nadaje sens i wskazuje cel zbiorowym oraz indywidualnym dążeniom ludzkim. Właśnie taki sens działaniom Konstantyna i Metodego nadali ich hagiografowie.

Inna grupa definicji intelektualistów to definicje socjologiczne, określające ich jako kategorię lub warstwę społeczną. Robert Michels (1999: 293) wskazuje na cechy intelektualistów jako differentia specifica tej kategorii społecznej. Intelektualiści są posiadaczami wiedzy teoretycznej, a ich podstawowym dążeniem jest osiąganie wolności myślenia. Zasadnicza funkcja społeczna intelektualistów polega na buntowaniu się przeciw wszystkiemu, co przeszkadza wolności myślenia i nauczania, wolności głoszenia poglądów. Posiadając wiedzę, której nie mają inni, często popadają w konflikt $\mathrm{z}$ istniejącym porządkiem społecznym, który wydaje im się anachroniczny. Stosując wiedzę w swojej działalności praktycznej, przyczyniają się do podnoszenia poziomu zaspokajania potrzeb ludności. Najpewniej piszący żywoty Konstantyna i Metodego byli wyrazicielami buntu elity obrządku słowiańskiego przeciwko ograniczeniu możliwości nauczania i głoszenia poglądów zgodnych z nauką Konstantyna i Metodego. Posiadali księgi liturgiczne spisane w języku słowiańskim, ale nie mogli głosić Ewangelii w tym języku, bo anachroniczne struktury obrządku łacińskiego nie dopuszczały do takiej możliwości. Nie mogli zatem zaspokajać potrzeb ludności morawskiej, aby mogła wysłuchać mszy świętych w języku słowiańskim.

W definicji Friedricha A. Hayeka intelektualiści nie są klasą twórców kultury, lecz klasą pośredników, przekazującą szerokim masom idee i wartości kulturalne. Intelektualiści to secondhand dealers in ideas. Są to więc ludzie pióra i słowa, będący specjalnym tworem społeczeństw powołanym dla upowszechniania wiedzy i idei. Definicja i teoria F.A. Hayeka, zrodzona z jego walki 
przeciwko totalitarnej ideologii socjalistycznej, została skonstruowana dla uzasadnienia i przeprowadzenia tezy politycznej, że intelektualiści, wybierając służbę dla socjalizmu, zwalczają wolność (Hayek 2010). W tym kontekście i hagiografowie Braci Sołuńskich, będąc przeciwnikami kleru skupionego wokół Wichinga, mogli toczyć walkę o wolność z „,iemnym totalitaryzmem łacińskim”.

$Z$ rozmaitych definicji dotyczących ludzi, zajmujących się pracą umysłową, wynika, że stawiano ich ponad społeczeństwem, przypisywano im funkcje nie tylko nauczycieli, lecz moderatorów moralnych, strażników odwiecznych wartości. Wieloaspektowe traktowanie intelektualistów musiało w konsekwencji doprowadzić do ich mitologizacji. Jak wobec tego jednoznacznie definiować ich cechy społeczne, ich rolę kulturalną, ich wpływ na politykę, czy na zmianę istniejącego porządku społecznego?

Jan Szczepański przez mitologizację intelektualistów rozumiał procedurę polegającą na przypisywaniu im pewnych ogólnych cech na podstawie impresji, dla poparcia tez ideologicznych bez dostatecznego ich uzasadnienia materiałami historycznymi (Szczepański 1962: 17). Źródła tej mitologizacji tkwią w złożonych sytuacjach społecznych, w potrzebach praktycznych, w zastępowaniu wiedzy przez fantazje. W rozważaniach nad intelektualistami ulega się uogólnieniom, opartym na powierzchownych spostrzeżeniach, na szukaniu natury intelektualistów. Metodyczna skłonność do mitologizacji występuje w rozważaniach na temat funkcji spełnianej przez intelektualistów w społeczeństwie. Powody mitologizacji intelektualistów mają swoje źródło, z jednej strony, w społecznych, praktycznych i politycznych interesach różnych grup i warstw społecznych, $\mathrm{z}$ drugiej zaś, w różnych teoriach rozwoju społecznego, dostarczających najogólniejszych podstaw do oceny roli intelektualistów.

Brak precyzyjnej definicji terminu „funkcja” pozwala na definiowanie funkcji intelektualistów z jednej strony jako proroków i przywódców ludzkości, $\mathrm{z}$ drugiej jako gromady burzycieli porządku społecznego. Najczęściej jednak określano ich funkcje przez stosunek do systemów wartości. Teoria klerków J. Bendy opiera się na założeniu, że istnieją wartości odwieczne, ponadhistoryczne a zadanie intelektualistów polega na przypominaniu, narzucaniu, zestawianiu i porównywaniu tych wartości z otaczającą ich rzeczywistością społeczną. J. Benda założył, że istnieje prosty i zrozumiały mechanizm zależności między wartościami odwiecznymi a procesami życia społecznego we wszystkich jego przejawach. Wystarczy, że klerkowie nie angażują się czynnie w politykę, nie ulegają namiętnościom ideologicznym, lecz tylko przypominają i głoszą dyrektywy wynikające z odwiecznych wartości i krytykują to, co z nimi nie jest zgodne. Niewątpliwie J. Benda zapomniał, że byli oni tylko ludźmi, którzy musieli żyć i zdobywać środki do życia, że na co dzień żyli w określonych społecznościach. J. Szczepański 
podkreśla, że J. Benda pomija ten cały mechanizm zależności między codziennym życiem klerka a pełnionymi przez niego funkcjami, między jego osobistymi dążeniami i wzorami życia zbiorowego a funkcjami klerka. Teoria J. Bendy jest zatem typowym przykładem braku analizy społecznego mechanizmu, poprzez który intelektualista oddziałuje, w jaki sposób systemy wartości, idee społeczne i estetyczne kształtują konkretne zachowania ludzi. Intelektualista głosi pewne idee ogólne i pokazuje systemy wartości. Dlaczego więc, zastanawia się J. Szczepański, niektóre z nich docierają i przyjmują się w społeczeństwach, a inne pozostają w wąskim kręgu, jeszcze inne - choć docierają szeroko - szybko zanikają (Szczepański 1962: 18).

Mitologizacja funkcji intelektualistów wynikała w znacznej mierze z braku dokładnej odpowiedzi na postawione pytania. Przyjmowano teorię zastępczą, orzekającą, że sama wartość dzieła intelektualisty była już decydującym czynnikiem wpływów społecznych. Z założenia dziełom o wartości naukowej, artystycznej czy moralnej przypisywano duży wpływ społeczny. Zatem wpływu społecznego i doniosłości spełnianej funkcji społecznej, zależnej od wpływu wywieranego rzeczywiście na zachowania i działania ludzi, nie można mierzyć doskonałością dzieła. Dzieło niezauważone z punktu rozwoju idealnego systemu wartości mogło być wielkim przyczynkiem, a z punktu widzenia spełniania funkcji społecznej nie istniało i na odwrót.

Mówiąc o wpływie wywieranym przez intelektualistę na zachowania i działania ludzi, należy odróżnić jego różne aspekty. Może to być wpływ intencjonalny, tzn. taki wpływ, który twórca chciał osiągnąć, rozpoczynając swoje dzieło. Może to być wpływ jego idei lub działalności wychodzący poza zamierzone intencje twórcy, obejmujący wszystkie konsekwencje wynikające $\mathrm{z}$ różnic percepcji, postaw i nastawień ludzi reagujących na dzieło czy aktywność intelektualisty. Może to być wpływ intelektualisty poza sferą jego twórczości, kiedy angażuje się społecznie lub politycznie, a swój autorytet zdobyty w dziedzinie twórczości wykorzystuje do wywarcia wpływu na postępowanie i na przekonania innych ludzi. Może to być wpływ nie intencjonalny, wywierany przez społeczne lub polityczne zaangażowanie. Według J. Szczepańskiego analizując funkcję intelektualisty w danej społeczności, trzeba starannie odróżnić, o który z tych czterech rodzajów wpływu chodzi (Szczepański 1962: 19).

Źródłem mitologizacji intelektualistów był również brak empirycznych badań nad osobowością twórców i ich rzeczywistymi cechami osobowymi. To powodowało, że traktowano ich jako legendarnych bohaterów mających wyłącznie cechy nadzwyczajne, pozwalające na tworzenie wielkich dzieł. Takie podejście wywodzono z założenia, że twórcy mają cechy wielkiego umysłu i charyzmatycznego 
charakteru. Wynikało to $\mathrm{z}$ prostego mechanizmu społecznego. O intelektualistach piszą zazwyczaj inni intelektualiści, traktując swoje opracowania jako przyczynek do podniesienia sławy i cnoty swojego bohatera. Z jednej strony chciano przekonać innych o wielkiej wartości opisywanego bohatera, stąd tendencja do idealizowania i upiększania jego życia. Z drugiej strony chciano świadomie lub nieświadomie podnieść własne zasługi, nadać większe walory swojemu własnemu dziełu i nadać opisywanej postaci taki blask, żeby część jego spadła i na biografa. Poza tym biografie i historie dzieła pisywali zazwyczaj ludzie, którzy sami nie mieli dość siły, aby tworzyć w danej dziedzinie i stąd gloryfikowali dzieła stworzone przez innych. Trzeba także wskazać na powszechną tendencję do idealizowania i mitologizowania swoich bohaterów, niechętnie bowiem pisano o cechach przyziemnych i zwyczajnych wybranych osobowości. „Wielkość” swoich dzieł twórcy byli skłonni tłumaczyć wyłącznie doskonałością i wielkością ludzi, którzy je stworzyli, a wzniosłość dzieła była odbiciem wzniosłości twórców. Zdaniem J. Szczepańskiego, ten rodzaj mitologizacji polega na upraszczaniu zależności między osobowością a jej wpływem na rozwój systemów wartości i na ludzkie postępowanie (Szczepański 1962: 20). Takie uproszczenie opiera się na tezie, że tylko wielkie i doskonałe osobowości mogły wywierać głęboki i trwały wpływ. Stąd historycy i biografowie z reguły nakładali aureole opisywanym intelektualistom. W kontekście takiej konwencji jest zupełnie zrozumiała tendencja do przedstawienia i opisania życia i dzieła Konstantyna i Metodego przez ich hagiografów. Uciekali się oni do prostych psychologicznych konstrukcji wywodzących działalność misyjną Braci Sołuńskich z ich wyjątkowych cech osobowości. Wyraźnie też w obu Żywotach zaniedbano te dziedziny życia Konstantyna i Metodego, które nie były bezpośrednio związane z ich dziełem misyjnym.

Julien Benda w swej teorii dotyczącej klerków widział w nich tylko postacie wyidealizowane, jeżeli nie wprost kanonizowane. Uważał, że biografowie słusznie pomijali nieważne ,marginesy” działalności klerków, skupiając się na rzeczywistej działalności, wynikającej z ich prawdziwego powołania. W ten sposób powstawały biografie jednostronne, stwarzające pozory, że intelektualiści byli i są ludźmi żyjącymi w świecie stworzonym przez ich własne umysły. Stąd także powstał mit, że intelektualiści są ludźmi nie ponoszącymi odpowiedzialności za sprawy praktyczne, nie rozumiejącymi lub ukrywającymi ,,prawdziwe życie”.

Mitologizacja intelektualistów wynikała także stąd, że nie przywiązywano wagi do danych biograficznych, pozwalających na uchwycenie zjawisk występujących i zachodzących wśród intelektualistów. Chodziłoby o uchwycenie cech społecznych, typów działalności, czy zaangażowania społecznego lub politycznego 
w pewnym okresie czasu. Badanie okoliczności powstania dzieła i odtworzenie tła historyczno-społecznego byłoby tutaj najbardziej wskazane. Jak zauważył J. Szczepański, najczęściej autorzy, pisząc o intelektualistach, stosowali swoistą metodę „typów idealnych”, polegającą na konstruowaniu „natury” swoich bohaterów i na dedukowaniu z tej natury funkcji, jakie mogą oni pełnić w społeczeństwie (Szczepański 1962: 22). Jeżeli jednak wszystkim przypisze się analogiczne cechy, postawy i dążenia, to zamiast opisu rzeczywistości powstanie mit.

Przyczyną metodologiczną mitologizacji intelektualistów może być często stosowane definiowanie ich jako „ludzi idei” (men of ideas) (Szczepański 1962: 22-23). Stąd ich społeczną ważność określano przez doniosłość tworzonych przez nich idei. Obok niewątpliwej słuszności takiego twierdzenia, powstawało również wiele nieporozumień i niebezpieczeństw deformujących rzeczywistość. Autorzy piszący o wpływie danej idei na społeczeństwo nie dysponują równocześnie systematyczną teorią wyjaśniającą, jak takie idee oddziałują na zbiorowości ludzkie. W konsekwencji różne teorie określające naturę idei i różne hipotezy wyjaśniające, jak idee wpływają na życie zbiorowe, wywierały mitologizujące piętno na rozważaniach o społecznej roli intelektualistów. W wielu przypadkach można odnaleźć wyraźny wpływ platońskiego rozumienia idei. Nikt nie twierdzi, że intelektualiści to twórcy idei w sensie platońskim, choć wiele systemów filozoficznych rozpatrujących rzeczywistość duchową jako pierwotną wywarło poważny wpływ na myślenie o ludziach, przyczyniających się do tworzenia takiej rzeczywistości. Jednocześnie traktowanie języka jako potężnego czynnika kształtującego nie tylko percepcję rzeczywistości, lecz i samą rzeczywistość, przyczyniło się do utwierdzenia przekonania, że ludzie tworzący aparat językowy wpływają także na rzeczywistość opisywaną. Nie inaczej można domniemywać w przypadku hagiografów Konstantyna i Metodego, którzy nie tylko tworzyli w słowiańskim języku literackim, ale przez napisanie dwóch Żywotów świętych w tym języku wpływali na rzeczywistość społeczną wtedy i w przyszłości.

W rozważaniach o społecznej roli intelektualistów, zdefiniowanych jako ludzie idei, jest oczywiste, że wywierali oni głęboki wpływ na życie zbiorowe ludzi. I nie ważne, czy idee zdefiniujemy jako pojęcia ogólne, jako teorie naukowe, jako artystyczne wizje świata, jako zasady moralne, czy jako religijne wizje świata transcendentnego. Nie ważne też, czy idee stają się czynnikiem subiektywnej definicji obiektywnego świata i sytuacji, na które człowiek reaguje, zawsze bowiem są one czynnikiem wyznaczającym zachowania. Intelektualiści formułują myśli w pojęciach ogólnych, nadają wyraz zamierzeniom i dążeniom, nadziejom i oczekiwaniom, utrzymują je w postaci sugestywnych sformułowań literackich, sloganów i haseł propagandowych, norm i zakazów moralnych i w ten sposób dostarczają jednostkom i grupom gotowych wzorów myślenia i działania. Są oni ludźmi, „którym idee zjawiają się jak objawienia”, i są oni ,żywym wcieleniem myśli 
pewnego okresu i w ich życiu konflikty okresu występują na ostrzu konfliktów sumienia" (Bronowski, Mazlish 1960: XII).

Niewątpliwie, do wielu intelektualistów wyżej cytowane sformułowanie może być w pełni zastosowane. J. Szczepański zastanawiał się, do jakiego odsetka intelektualistów żyjących i działających w pewnym okresie można je użyć i w jakiej mierze? Może się bowiem zdarzyć, że ludzie, uważani przez historyków za tych, którzy objawiali idee epoki i wyrażali jej konflikty, za czasów swojego życia mogli być prawie nieznani. W każdym pokoleniu kulturalnej historii Europy istniało kilku wybitnych intelektualistów i wielka rzesza przeciętnych, pracujących w różnych dziedzinach kultury i aktywności społecznej. Między tymi dwoma kategoriami mogło nie być żadnej styczności. Zapewne ludzie, którzy przepędzili z Moraw wyznawców liturgii słowiańskiej, bardzo mało wiedzieli o idei, przekazanej w Żywotach Konstantyna i Metodego, dziś uważanej za wcielenie umysłowości tamtej epoki.

$\mathrm{Z}$ takiej to nieznajomości rodzi się pewien rodzaj mitologizacji ludzi idei jako duchowych kierowników swojej epoki; rodzi się też z braku analizy rzeczywistego wzajemnego oddziaływania intelektualistów i ich środowisk społecznych. Ponadto nie rozróżniano dokładnie wpływu wywieranego przez twórców idei i wpływu samych idei przez nich sformułowanych, kiedy stawały się one już częściami systemów kulturalnych niezależnych od ich twórców. Mówiąc o wpływie ludzi idei, mamy zazwyczaj na myśli takich ludzi, jak Konstantyn i Metody. Jednak, gdy zwrócimy uwagę na krytyków ich dzieła, którzy równocześnie formułowali inne idee, którzy nawet cieszyli się poparciem bardzo potężnych grup i samego dworu książęcego, a którzy nie osiągnęli nawet cienia tego wpływu, co twórcy przez nich krytykowani, zobaczymy całą sprawę w innym aspekcie. Z jednej strony, ci krytycy mogli osiągnąć duży wpływ w swoich społecznościach, lecz bez szerszego zasięgu, z drugiej strony, te liczby krytyków mogły być znacznie większe od liczby zwolenników naszych myślicieli. Wielcy twórcy idei po prostu dopingowali swoich przeciwników do większego wysiłku twórczego. Ci zaś krytycy jako twórcy mogli rzeczywiście w pewnych okresach być przywódcami swoich społeczności, nie pozostawili jednak trwalszego dorobku pisarskiego, znanego pokoleniom późniejszym. Zdaniem J. Szczepańskiego (1962: 24), tylko drobiazgowe badania historyczno-statystyczne mogą pokazać, kto rzeczywiście był żywym wcieleniem idei swojej epoki i jaka była rzeczywista funkcja tych myślicieli, których późniejsi biografowie kreowali na przywódców duchowych, kim byli ci ludzie, którzy rzeczywiście byli opinion leaders dla wielkich rzesz ludzkich, żyjących w społecznościach lokalnych i rzeczywiście kształtowali ich poglądy, postawy i działania. Określenie men of ideas, zakładające milcząco różne definicje idei i różne koncepcje społecznego oddziaływania idei, wypacza częstokroć obraz rzeczywistości. 
Źródło mitologizacji intelektualistów tkwi także w oddzieleniu badań i rozważań nad nimi od badań i rozważań nad rozwojem społeczeństwa. W toku omawiania różnych definicji każda koncepcja społecznej roli intelektualistów i ocena ich działalności zależała $\mathrm{w}$ znacznej mierze od świadomie czy nieświadomie przyjętej teorii rozwoju społecznego. Oddzielenie rozważań nad rolą intelektualistów od tła rozwoju społecznego prowadzi do ,absolutyzowania” intelektualistów lub wytworów ich działalności. Teorie, które zasadniczą funkcję intelektualistów widzą w „uduchowieniu” życia społecznego, zakładają, że mogą ignorować wszelkie przekształcenia zachodzące w obiektywnych strukturach społecznych, bo np. funkcja nauczania jest zawsze identyczna lub bardzo podobna. Jednakże chwila refleksji nad nauczaniem misyjnym w IX i XI w., porównanie jego zasięgu i skutków pokaże nam, że pełne zrozumienie i wyjaśnienie nauczania misyjnego jest możliwe tylko na podstawie zmieniających się struktur społeczeństwa, i w odniesieniu do zmian w tym społeczeństwie zachodzących.

Podobną deformację wywołuje ,absolutyzowanie” idei. Takie idee jak ,,sprawiedliwość”, czy „dobro” mają różną treść społeczną i inaczej są rozumiane w różnych okresach historycznych. Studiowanie treści idei niezależnie od zmian, a raczej przyjmowanie, że idee mają zawsze analogiczną treść, i że „sprawiedliwość”, jest zawsze jednakowo rozumiana, jest uproszczeniem prowadzącym do mitu, że i funkcje intelektualistów broniących tej sprawiedliwości są zawsze identyczne.

Można tu podnieść zastrzeżenie, że idee są czynnikiem trwałości i ciągłości społeczeństw w czasie, i że trwałość dziedzictwa kulturalnego danego narodu składa się z jego idei filozoficznych, artystycznych, moralnych, które działają jako symbole narodowej jedności i narodowej identyczności poprzez dzieje. Jan Szczepański sądził, że trzeba tu rozróżnić zagadnienie trwałości i niezmienności idei, które jest zagadnieniem metafizycznym od zagadnienia percepcji tych idei przez kolejne pokolenia i zmian, jakie powstają w ich rozumieniu i reagowaniu na nie (Szczepański 1962: 25).

Teoria rozwoju społecznego ma więc dwojaki wpływ na badania nad intelektualistami: po pierwsze, zależnie od przyjętej teorii rozwoju przyjmuje się kryteria oceny wyników ich działalności; po drugie, teoria rozwoju staje się podstawą interpretacji funkcjonowania idei wytworzonych przez intelektualistów, a zatem także podstawą badań nad ich obiektywnym wpływem, niezależnym od intencji twórców. Oderwanie tych badań od studiów nad rozwojem całości systemów społecznych musi prowadzić do uproszczeń i deformacji.

Jakże ważnym źródłem mitologizacji intelektualistów jest brak opracowanego systemu zróżnicowania społecznego, traktowanie intelektualistów jako jednorodej warstwy czy grupy społecznej, wypełniającej tożsame funkcje i mającej identyczne cechy społeczne. Takie uproszczenie miało poważny wpływ na wytwarzanie 
się stereotypu, polegającego na przypisywaniu wszystkim kategoriom ludzi pracy umysłowej cech posiadanych przez jedną kategorię, np. filozofów. Znamienne, że Konstantyn przez jemu współczesnych nazywany był Filozofem. Niemniej wraz z rozwojem społeczeństw proces różnicowania społecznego ludzi zajmujących się pracą umysłową postępował niesłychanie szybko. Podobnie zmiany ustrojów ekonomicznych i politycznych podnosiły stopień ich zróżnicowania.

Na zakończenie rozważań o intelektualistach warto zaznaczyć, że intelektualiści pisząc o sobie, częściej tworzyli mity niż empirycznie zweryfikowane opisy i uogólnienia. Chcąc nieco odmitologizować intelektualistów w różnych okresach historycznych, należałoby próbować opisywać zróżnicowanie społeczne intelektualistów, analizować czynności wykonywane przez nich w różnych społeczeństwach i definiować ich funkcje jako proces zaspokajania potrzeb. W ten sposób można odkryć społeczne mechanizmy, poprzez które intelektualiści pośrednio lub bezpośrednio przyczyniali się do zaspokajania potrzeb jednostek i grup.

\section{Bibliografia}

Aron R. (2000), Opium intelektualistów, tłum. Cz. Miłosz, Muza, Warszawa.

Bacon F. (1826), The Works of Francis Bacon, n.ed., vol. I, London.

Benda J. (2003), La Trahison des clercs, Grasset, Paris.

Bronowski J., Mazlish B. (1960), The Western Intellectual Tradition. From Leonardo to Hegel, Harper and Brothers, New York.

Hayek F.A. (2010), The Intellectuals and Socialism (1949), rep., Kessinger Publishing, Chicago.

Michels R. (1999), Political Parties. A Sociological Study of the Oligarchical Tendencies of Modern Democracy, Transaction Publishers, New Brunswick.

Ortega y Gasset J. (2008), Bunt mas, tłum. P. Niklewicz, Muza, Warszawa.

Szczepański J. (1961), Intellectuals in Contemporary Societies, Part I, Center for Advanced Study in the Behavioral Sciences, Stanford.

Szczepański J. (1962), Mitologizacja intelektualistów, „Studia Socjologiczne”, nr 3.

Żywoty Konstantyna i Metodego (obszerne), przeł. T. Lehr-Spławiński, wyd. nowe, Warszawa 2000. 